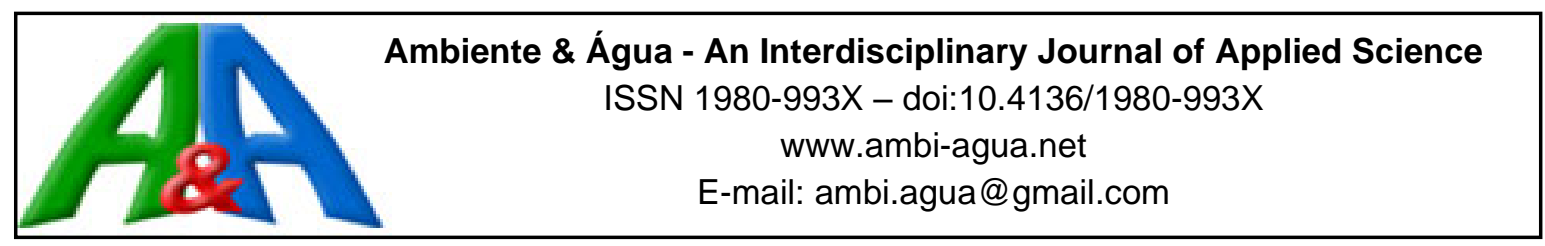

\title{
Probability of rainfall for the city of Cruzeiro do Sul, Acre, Brazil
}

\author{
ARTICLES doi:10.4136/ambi-agua.2593
}

Received: 09 Jun. 2020; Accepted: 03 Nov. 2020

\author{
Jefferson Rodrigues dos Santos Silva ${ }^{1}$; ; Matheus Kucmanski Taveira2 ${ }^{2}$; \\ Rodrigo Otávio Peréa Serrano ${ }^{1}$; Anderson Azevedo Mesquita ${ }^{3}{ }^{(D}$; \\ José Genivaldo do Vale Moreira ${ }^{4 *(i D)}$
}

\author{
${ }^{1}$ Programa de Pós-Graduação em Ciência, Inovação e Tecnologia para a Amazônia (PPG-CITA). \\ Departamento de Filosofia e Ciências Humanas. Universidade Federal do Acre (UFAC), \\ Rodovia BR 364, Km 04, CEP: 69920-900, Rio Branco, AC, Brazil. \\ E-mail: jeffersonrodriguesssilva@gmail.com,ropereas@gmail.com \\ 2Departamento de Agronomia. Universidade Federal do Acre (UFAC), Rodovia BR 364, Km 04, \\ CEP: 69920-900, Rio Branco, AC, Brazil. E-mail: matheustaveira.mt23@gmail.com \\ ${ }^{3}$ Departamento de Filosofia e Ciências Humanas. Universidade Federal do Acre (UFAC), Rodovia BR 364, \\ Km 04, CEP: 69920-900, Rio Branco, AC, Brazil. E-mail: amgeoufac@ hotmail.com \\ ${ }^{4}$ Universidade Federal do Acre (UFAC), Campus Floresta, Gleba Formoso, Lote 245, CEP: 69980-000, Cruzeiro \\ do Sul, AC, Brazil. \\ *Corresponding author. E-mail: genivaldoufac@gmail.com
}

\begin{abstract}
Due to randomness in the occurrence of hydrological phenomena, the estimation of probable rain precipitation in a given region is important in assisting decision-making. This work aimed to adjust the probabilistic model of the Gamma distribution to the monthly and annual rainfall totals recorded in the city of Cruzeiro do Sul, Acre, for the period between 1970 and 2019, in addition to estimating the expected values at different probability levels. Using the maximum likelihood method, the distribution parameters were estimated, with adherence ratified by the Kolmogorov-Smirnov test. The results showed that the Gamma distribution was adequate to adjust the data; the region has two well-defined periods in its rainfall pattern; the mean precipitation values recorded in the locality are between $25 \%$ and $40 \%$ of probability. Finally, probable rainfall values were presented at different probability levels for the city of Cruzeiro do Sul.
\end{abstract}

Keywords: agricultural planning, expected rain precipitation, probability distribution.

\section{Probabilidade de precipitação para a cidade de Cruzeiro do Sul, Acre, Brasil}

\section{RESUMO}

Devido a aleatoriedade na ocorrência dos fenômenos hidrológicos, a estimação das precipitações prováveis em determinada região é importante para auxiliar na tomada de decisão. O presente trabalho objetivou ajustar o modelo probabilístico da distribuição Gama aos totais mensais e anuais de precipitação pluviométrica registrados na cidade de Cruzeiro do Sul, Acre, para o período compreendido entre 1970 e 2019, além de estimar os valores esperados em diferentes níveis de probabilidade. Valendo-se do método da máxima verossimilhança foram 
estimados os parâmetros da distribuição, com aderência ratificada pelo teste de KolmogorovSmirnov. Os resultados apontaram que: a distribuição Gama mostrou-se adequada ao ajuste dos dados; a região possui dois períodos bem definidos em seu padrão pluviométrico; os valores médios de precipitação registrados na localidade estão entre $25 \%$ e $40 \%$ de probabilidade. Finalmente, foram apresentados valores prováveis de precipitação pluviométrica em diferentes níveis de probabilidade para a cidade de Cruzeiro do Sul.

Palavras-chave: distribuição de probabilidades, planejamento agrícola, precipitação esperada.

\section{INTRODUCTION}

Rainfall is a meteorological event with great influence on environmental conditions, as well as on various human activities. In fact, rain is a hydrological element that triggers many other processes, as it is the entry component into the water balance of a region, and the results of such interactions have influenced human activities for milenia (Moreira et al., 2016; Passos et al., 2017; Miguez et al., 2018; Santos et al., 2019).

Rain is the beginning of a process that results in providing basic human needs and boosting important activities, such as industry, agriculture, energy transformation, etc. In modern society, the hydrological elements related to rainfall strongly influence the social and economic development of nations (Baptista and Coelho, 2010; Moreira et al., 2016).

According to Martins et al. (2010), of all segments of the economy, agriculture represents the sector presenting the greatest dependence on climatic variables, especially concerning rainfall, whose impact is responsible for significant fluctuations over the years.

The region under study, for example, has cassava cultivation as the main agricultural product, which is important even in the national market. This crop culture, in turn, depends heavily on the spatial and temporal distribution of rainfall (Brito et al., 2019). Therefore, the results verified in the present study suggest favorable conditions for cassava cultivation, since they point to good rainfall distribution in the region, which presented a monthly average of more than $70 \mathrm{~mm}$, even in the less rainy months.

In this sense, the study conducted by Flores (2015) points out that, in the state of Acre, the cultivation of cassava crops is concentrated in the months at the start of the rainy season (October to December), ensuring the supply of water, indispensable for the initial growth of plants. The adequate rainfall amount is between 1,000 and $1,500 \mathrm{~mm} /$ year, well distributed;however, the crop produces reasonably well in localities with rainfall indexes of up to $4,000 \mathrm{~mm} /$ year, when this occurs on well drained soils (Souza et al., 2006).

Therefore, previous knowledge about the behavior of the rainfall regime in a particular region is of fundamental importance for agricultural planning, because the success of activities involving the sector is directly linked to the occurrence and magnitude of rainfall (Arai et al., 2009; Souza et al., 2018). Cassava crop, for example, of which Brazil is the fourth largest producer in the world, demands climatic conditions as a regulatory factor of its production, especially concerning the precipitation regime, which requires effective management of soil and drainage conditions (Martins et al., 2010; Soman et al., 2016; Moreto et al., 2018).

Given the importance of rainfall, especially in a regional context, the need to quantify and/or predict its occurrences has become an essential condition for the development of agricultural activities, besides many other productive segments. Thus, scientific and technological advances allowed the creation of efficient instruments aiming at this purpose, especially those proposed taking into consideration the basic characteristic of randomness present in the occurrence of these phenomena (Moreto et al., 2018; Bortoluzzi et al., 2019).

Because rainfall is a phenomenon dependent on several stochastic factors, the use of models inserted in the scope of probability distributions becomes coherent, which allows, 
among other things, the estimation of probable amounts of monthly or annual rain precipitation for a given locality. These instruments are important tools to assist decision-making in the planning of various activities related to agriculture, livestock, civil construction, transportation, etc. (Pizzato et al., 2012; Passos et al., 2017).

Indeed, the statistical modeling in hydrological studies is extremely important regarding the prediction of events associated with the probability of their occurrences, as elucidated by the study conducted by Abreu et al. (2018). In the work, the authors inserted the probability models in the relationship of practices allied to the rational planning of the various activities that depend on the dynamics involved in the occurrence of rainfall. In turn, Costa and Fernandes (2015) considered it as one of the basic stages sustaining decision-making, especially in the present context, whose theme is recurrent in the literature of the specialty.

In this sense, there are several distributions to be adjusted to the temporal record of hydrological variables. In the present context, in which it is proposed to estimate the total amounts of probable rainfall in the city of Cruzeiro do Sul, State of Acre, Brazil, contextualized in monthly and annual intervals, the Gamma distribution presents assumptions that give it prominence among the others (Teixeira et al., 2013; Bermudez et al., 2017; Abreu et al., 2018).

In the light of these considerations, the aim of the present work was to estimate the probable values of rainfall amount, at different probability levels, for the city of Cruzeiro do Sul, Acre, Brazil, based on the recorded events occurred in the period between 1970 and 2019, records of which are made available by the National Institute of Meteorology - INMET.

Among many factors to support the research, the productive potential of the region stands out, especially for the cassava cultivation, influenced by its pluviometric regime, which can impact both agricultural activity and other segments.

In addition, the realization of this work is justified, since the estimated values of rainfall precipitation can be influenced over time, due to several factors, among them, the climatic changes credited to anthropic actions, as well as those related to the natural climate variability that, collectively or in isolation, have an effect on the hydrological processes operating in the region (Moreira et al., 2019; Marengo and Souza Júnior, 2018).

\section{MATERIALS AND METHODS}

The city of Cruzeiro do Sul is located in the Vale do Juruá region, in the state of Acre. The predominant climate in the region, according to the Köppen classification, is the humid tropical (Af), with an average annual temperature of approximately $24.5^{\circ} \mathrm{C}$ (Moreira et al., 2016; 2019). However, given the nature of the work, Nimer's model was adopted as a reference, which seeks to integrate traditional and dynamic methods to better understand the complex ecological relationships of Brazilian biodiversity (Nimer, 1979). The climatic classification of Nimer (1979), prioritizes the influence of temperature and humidity on climatic diversity, and in turn, it is based on dynamic climatology and the rhythm of air masses. Thus, for the studied region, the Equatorial hot climate type is observed, with a daily average temperature above $18^{\circ} \mathrm{C}$ in all months, and with the distribution of humidity of the super-humid type to the sub-dry type (Figure 1).

The region has a drier period (May to September) and a notably rainy period (October to April), with annual rainfall averages of approximately 2,000 mm (Moreira et al. 2016; 2019). Therefore, it is observed that among the three zones of humidity variation identified in the classification of Nimer (1979), the Cruzeiro do Sul region is highlighted for having the highest moisture distribution.

In this work, the total monthly and annual rainfall data was used, computed for the city of Cruzeiro do Sul, during the period from 1970 to 2019, recorded at the meteorological station 82704 ( $7^{\circ} 38^{\prime} \mathrm{S} ; 72^{\circ} 40^{\prime} \mathrm{W}$, in datum WGS84), operated by the National Institute of Meteorology (INMET) (Souza et al., 2011; Moreira et al., 2019) (Figure 1). There are occasional failures in 
the records in the years 1991 and 1992, corresponding to $4 \%$ of the records, whose monthly values were filled out using the regional weighting method (Oliveira et al., 2010).

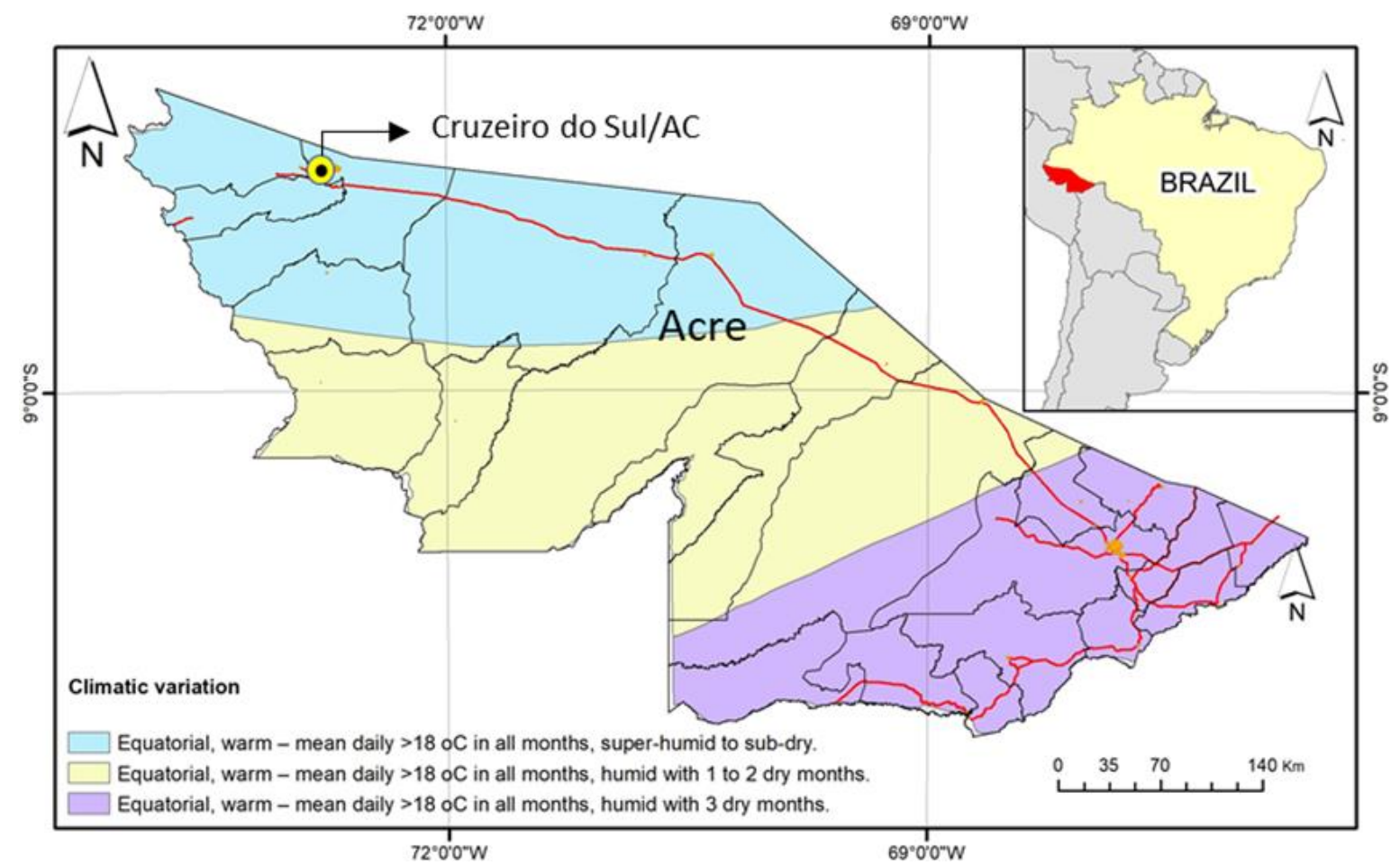

Figure 1. Location of the city of Cruzeiro do Sul and climatic variation throughout the State of Acre (Brazil).

Source: IBGE, 2018.

The data were adjusted to the Gamma distribution, which according to Araújo et al. (2001) and Bazame et al. (2018) is the most-used formulation to adjust total rainfall records. According to Passos et al. (2017), the Gamma distribution has been positively reported in several studies as a reliable probability distribution for the analysis of total rainfall. The authors used it to estimate the probable rainfall at different levels of probability for the Municipality of Chapadinha-MA. Dallacort et al. (2011) used the Gamma distribution in a study of total rainfall distribution in the city of Tangará da Serra, Mato Grosso, and reported satisfactory results.

The distribution parameters were estimated using the maximum likelihood method (Araújo et al., 2001; Barbieri et al., 2019). From there, the probable rainfall for the city of Cruzeiro do Sul was determined at different probability levels. As described by Araújo et al. (2001) and Martins et al. (2010), the cumulative function of probabilities of the distribution (CFP) of Gamma is given by Equation 1:

$\mathrm{F}(\mathrm{x})=\frac{1}{\Gamma(\alpha) \beta^{\alpha}} \int_{0}^{\mathrm{x}} \mathrm{x}^{\alpha-1} e^{-\frac{x}{\beta}} \mathrm{dx}$

In Equation 1, $\alpha$ is the shape parameter and $\beta$ is the scale parameter; $\mathrm{e}$ is the basis of the Napierian logarithm; $x$ represents the total rainfall $(\mathrm{mm})$; and $\Gamma(\alpha)$ is the symbol of the Gamma function, defined according to the function (Equation 2):

$$
\Gamma(\alpha)=\sqrt{2 \pi \alpha} \alpha^{\alpha} e^{\alpha}\left(1+\frac{1}{12 \alpha}+\frac{1}{288 \alpha^{2}}-\frac{139}{51840 \alpha^{3}}\right)
$$


As described by Araújo et al. (2001) and Teixeira et al. (2013), the parameters that allow the cumulative Gamma distribution, estimated by the maximum likelihood method, are determined by the following Equations ( 3 and 4):

In which:

$\beta=\frac{\bar{x}}{\alpha} \quad$ e $\quad \alpha=\frac{1}{4 A}\left(1+\sqrt{1+\frac{4 A}{3}}\right)$

$\mathrm{A}=\ln (\bar{X})-X_{g}$

In Equation 4, $\bar{X}$ represents the arithmetic mean of the observation series, $X_{g}$ the geometric mean, and $\mathrm{N}$ represents the number of elements in the historical series under test.

The adherence of data adjustment to the Gamma distribution was verified using the Kolmogorov-Smirnov test (KS test), at the significance level of 5\% (Marsaglia et al., 2003; Silva, 2015; Moreira et al., 2016).

Finally, the probable rainfall quantiles associated with probability levels of 5, 10, 25, 40, $50,60,75,90$, and $95 \%$ were determined. It should be noted that, because the calculations would require too much effort and complex routine, they were carried out using statistical software specially designed for this purpose, such as the packages base and fitdistrplus $\mathrm{R}$ packages (Delignette-Muller and Dutang, 2015; R Core Team, 2019) in addition to the ALEA (Local Frequency Analysis of Annual Events) (Lima et al., 2015).

\section{RESULTS AND DISCUSSION}

Table 1 presents a descriptive summary related to total, monthly, and annual rainfall recorded for the city of Cruzeiro do Sul, Acre, for the period from 1970 to 2019.

Table 1. Descriptive summary of total, monthly, and annual rainfall observations recorded in Cruzeiro do Sul, Acre, from 1970 to 2019. Estimated parameters $\alpha$ (form) and $\beta$ (scale) of the Gamma distribution and test and p-value statistics referring to the KolmogorovSmirnov adherence test for the data under analysis.

\begin{tabular}{ccccccccc}
\hline \multirow{2}{*}{ Month } & \multirow{2}{*}{$\begin{array}{c}\text { Mean } \\
(\mathrm{mm})\end{array}$} & \multirow{2}{*}{$\begin{array}{c}\text { Minimal } \\
(\mathrm{mm})\end{array}$} & $\begin{array}{c}\text { Maximal } \\
(\mathrm{mm})\end{array}$ & $\begin{array}{c}\mathrm{CV} \\
(\%)\end{array}$ & $\begin{array}{c}\alpha \\
\text { (form) }\end{array}$ & $\begin{array}{c}\beta \\
(\text { scale) }\end{array}$ & \multicolumn{2}{c}{ Test KS } \\
\hline January & 246.20 & 75.50 & 484.00 & 35.87 & 7.12 & 34.57 & 0.10 & $0.69^{\mathrm{NS}}$ \\
February & 246.20 & 61.80 & 454.80 & 35.71 & 6.78 & 36.31 & 0.09 & $0.85^{\mathrm{NS}}$ \\
March & 273.90 & 40.80 & 448.50 & 35.94 & 6.41 & 42.71 & 0.11 & $0.62^{\mathrm{NS}}$ \\
April & 216.40 & 59.80 & 448.70 & 38.48 & 6.37 & 33.95 & 0.11 & $0.55^{\mathrm{NS}}$ \\
May & 148.40 & 42.20 & 308.00 & 43.24 & 5.16 & 28.72 & 0.11 & $0.61^{\mathrm{NS}}$ \\
June & 88.33 & 1.20 & 219.20 & 54.68 & 2.68 & 33.01 & 0.09 & $0.82^{\mathrm{NS}}$ \\
July & 70.26 & 4.20 & 230.90 & 71.65 & 1.87 & 37.63 & 0.08 & $0.83^{\mathrm{NS}}$ \\
August & 77.28 & 10.50 & 194.70 & 46.62 & 4.24 & 18.21 & 0.11 & $0.56^{\mathrm{NS}}$ \\
September & 122.90 & 30.20 & 340.30 & 54.79 & 3.31 & 37.05 & 0.10 & $0.69^{\mathrm{NS}}$ \\
October & 196.70 & 62.60 & 508.70 & 47.49 & 5.26 & 37.39 & 0.15 & $0.20^{\mathrm{NS}}$ \\
November & 210.20 & 54.80 & 480.20 & 44.38 & 5.09 & 41.24 & 0.06 & $0.99^{\mathrm{NS}}$ \\
December & 240.30 & 99.00 & 438.10 & 32.38 & 9.49 & 25.31 & 0.09 & $0.81^{\mathrm{NS}}$ \\
\hline Annual & $2,137.00$ & $1,100.50$ & $2,848.10$ & 18.03 & 27.60 & 77.42 & 0.13 & $0.39^{\mathrm{NS}}$ \\
\hline
\end{tabular}

$\mathrm{CV}=$ Coefficient of Variation; NS = Not significant, at significance level 5\%.

From the descriptive summary presented in Table 1, it was observed that the month of March presented the highest average value of total monthly precipitation for the period under 
analysis, while the lowest value was observed for the month of July, which is typical for a subarid month, with precipitations greater than $60 \mathrm{~mm}$, constructed based in the climate classification of Nimer (1979).

It was also verified that the total monthly precipitation recorded in Cruzeiro do Sul presented great variability, with a coefficient of variation between $32.38 \%$ and $71.65 \%$, being the highest value observed during the dry period (low average value of total monthly precipitation), whereas the lowest variation is associated with the rainy season. Many causes can be related to the variability observed, including the atmospheric circulation patterns prevalent in the Amazon region, influenced by disturbances both on a regional and global scale. Such disturbances affect the hydrological regime of the region in its temporal scale (Nobre et al., 2007; Nóbrega, 2014). In addition, other processes such as ENSO (El Niño - Southern Oscillation), SACZ (Southern Atlantic Convergence Zone), among others, may be related to this variability, since the study proposed by Santos et al. (2013) presented as part of its conclusions that such singularities influence the rainfall regime of the Amazon, which encompasses the region under study. In addition, it was found that the city of Cruzeiro do Sul presented an average annual rainfall value of 2,137 $\mathrm{mm}$ for the period under study.

The descriptive values also show that the locality under study has a rainfall pattern characterized by two well-defined periods: a sub-arid period, according to the climatic classification of Nimer (1979), between the months of May to September, with emphasis on the months of July and August, which presented the lowest mean values of rainfall (Table 1); and a remarkably rainy period, specially from October to April. This verification confirms the characteristics reported by Moreira et al. (2016), whose study also analyzed the rainfall regime in the city of Cruzeiro Sul, but with a different objective than that of this work.

Regarding the period of higher and lower rainfall concentration, the conclusions presented in the study conducted by Silva et al. (2019) indicate that the rainfall regime of the region that covers the municipality of Goiana, in the state of Pernambuco, Brazil, is different than the results found in the present study. In their work, the authors conclude that the month of June is the rainiest, while the month of November has the lowest volume of rainfall. The study conducted by Bezerra et al. (2010), obtained results similar to the present study on the rainfall regime, registered in Porto Velho. The comparisons reveal the importance of studies on a regional scale in relation to the planning of activities that are impacted by the rainfall regime, especially in projects focused on the agricultural sector, because of the particularities of each kind of crop culture and region.

Table 1 also presents the estimated parameters of the Gamma distribution ( $\alpha$ and $\beta$ ), in addition to the results related to the Kolmogorov-Smirnov adherence test (KS test). The results from the KS test were sufficient to conclude that the Gamma distribution was adequately adjusted to the observed rainfall records, both monthly and annual, because the p-value associated with each statistic calculated value of the test was higher than the level of significance adopted (5\%). This conclusion is in accordance with that presented in the study proposed by Silva et al. (2019), where the authors attest that this distribution can thus be used to estimate amounts of probable rainfall.

In relation to the parameters of form and scale ( $\alpha$ and $\beta$ ), estimated by the maximum likelihood method, they were adequate to the rainfall data analyzed, both in monthly and annual interstices, since none of the estimated values for the scale parameter was higher than 100, which condition recommends the use of the Gamma distribution for the determination of probable precipitation values, as reported in several studies (Araújo et al., 2001; Martins et al., 2010; Silva et al., 2019). In relation to the form parameter, Silva et al. (2019) point out that it should not exceed the value of 10 . Thus, the values estimated from the rainfall observations analyzed were below the limiting value and, therefore, the distribution, as it is proposed, is adequate to the estimate of probable rainfall values in the city of Cruzeiro do Sul, and thus it is 
maintained.

It was verified, in the present study, that the interannual variation of the values of total monthly precipitation recorded in Cruzeiro do Sul, represented in Table 1 by the coefficient of variation $(\mathrm{CV})$, is higher for the months in which the form parameter $(\alpha)$ presents its lowest values. The interval is coincident with the dry period, in which the lowest average values of the monthly rainfall records are concentrated.

The study conducted by Martins et al. (2010) presented an inverse conclusion to that of the present study, regarding the relationship between the interannual variation and the form parameter. However, the conclusions of both converge to the indication that this parameter can be used in the determination of regular periods of precipitation.

Table 2 lists the values of probable monthly and annual rainfall at different probability levels estimated for the city of Cruzeiro do Sul according to the Gamma distribution. The results presented show that, in general, the average values of total rainfall, both monthly and annual, recorded for the city of Cruzeiro do Sul during the period in study, are equivalent to estimated values included in the range between the levels of $25 \%$ and $40 \%$ of probability (Table 1 ). This characteristic is observed in many studies related to probable rainfall for different regions and/or hydrological contexts (Martins et al., 2010; Passos et al., 2017). On the other hand, there are reports in which the average records, although close to values verified in this study, are in a different range of probability levels, as was verified by Silva et al. (2013), who studied distribution of rainfall in the city of Sapezal, State of Mato Grosso, Brazil.

The probable rainfall values, shown in Table 2, are important elements to support the rational planning of activities that depend on this hydrological variable, such as agricultural activity. Since the region under study has potential for cassava cultivation (Brito et al., 2019), the probable rainfall values with a certain margin of confidence promote more consistent decision-making in agricultural planning and for the most diverse areas of knowledge.

It is noteworthy, nevertheless, that both the scientific community and other organizations are already reaching the consensus that the impacts of climate change (on a global and/or regional scale) are already influential on the Amazon. As a result, the rainfall regime in the region under study may change its patterns and, consequently, the estimated values, since hydrological processes, especially rainfall regime, are quite sensitive to climate change (Moreira et al., 2019; Marengo and Souza Júnior, 2018).

\section{CONCLUSIONS}

The study produced satisfactory results that may serve as a catalyst for further discussion and development, and reached the following conclusions: 1) The Gamma probability model was adequately adjusted to the total monthly and annual rainfall data computed for the city of Cruzeiro do Sul, Acre; 2) The region under study presents a rainfall pattern defined in two welldefined periods: a sub-dry period, between the months of May and September, in special the months of July and August, in addition to a remarkably rainy period, more evident in the period from October to April; and, 3) The average values of total precipitation, both monthly and annually, recorded in the city of Cruzeiro do Sul during the period from 1970 to 2019, are equivalent to estimated values included in the range between the levels of $25 \%$ and $40 \%$ of probability.

The conclusions are in accordance with the study's objectives, and will serve as a basis for further studies in the region. It will also provide support and decision-making tools, especially with regard to agricultural activity, which depends on estimated rainfall values.

It is important to emphasize that, even with favorable results, it is not intended that the discussion end here; rather, hypotheses regarding the behavior of phenomena that operate in the region must be evaluated, and future studies with suitable methodology must be conducted in similar and dissimilar regions as appropriate.

Rev. Ambient. Água vol. 16 n. 1, e2593 - Taubaté 2021 
Table 2. Probable monthly and annual rainfall for the city of Cruzeiro do Sul, Acre, at different probability levels, estimated according to the Gamma probability distribution.

\begin{tabular}{cccccccccc}
\hline \multirow{2}{*}{ Month } & \multicolumn{7}{c}{ Probable pluviometric precipitation (mm) } \\
\cline { 2 - 9 } & $5 \%$ & $10 \%$ & $25 \%$ & $40 \%$ & $50 \%$ & $60 \%$ & $75 \%$ & $90 \%$ & $95 \%$ \\
\hline January & 414.86 & 369.28 & 300.57 & 258.20 & 234.73 & 212.74 & 179.33 & 137.79 & 116.43 \\
February & 419.47 & 372.45 & 301.73 & 258.24 & 234.20 & 211.70 & 177.63 & 135.43 & 113.85 \\
March & 472.53 & 418.34 & 337.06 & 287.23 & 259.76 & 234.10 & 195.34 & 147.59 & 123.30 \\
April & 373.90 & 330.92 & 266.46 & 226.96 & 205.18 & 184.85 & 154.15 & 116.35 & 97.14 \\
May & 269.50 & 235.79 & 185.75 & 155.47 & 138.94 & 123.64 & 100.79 & 73.26 & 59.59 \\
June & 191.62 & 160.67 & 116.43 & 90.96 & 77.58 & 65.61 & 48.62 & 29.94 & 21.65 \\
July & 170.35 & 138.89 & 95.02 & 70.63 & 58.19 & 47.33 & 32.53 & 17.47 & 11.42 \\
August & 147.48 & 127.54 & 98.24 & 80.74 & 71.29 & 62.61 & 49.82 & 34.75 & 27.47 \\
September & 250.67 & 213.37 & 159.33 & 127.65 & 110.78 & 95.48 & 73.35 & 48.14 & 36.46 \\
October & 335.73 & 311.55 & 245.92 & 206.17 & 184.44 & 164.31 & 134.23 & 97.9 & 79.84 \\
November & 383.01 & 334.85 & 263.39 & 220.20 & 196.64 & 174.82 & 142.30 & 103.15 & 83.76 \\
December & 381.27 & 344.07 & 287.31 & 251.79 & 231.90 & 213.08 & 184.13 & 147.31 & 127.91 \\
\hline Annual & $2,847.02$ & $2,671.97$ & $2,395.46$ & $2,215.18$ & $2,111.20$ & $2,010.53$ & $1,850.39$ & $1,635.06$ & $1,514.73$ \\
\hline
\end{tabular}




\section{ACKNOWLEDGEMENTS}

The authors wish to thank UFAC, INMET, CAPES, and the CNPq for financially supporting this research.

\section{REFERENCES}

ABREU, M. C.; CECILIO, R. A.; PRUSKI, F. F.; SANTOS, G. R.; ALMEIDA, L. T.; ZANETTI, S. S. Critérios para escolha de distribuições de probabilidades em estudos de eventos extremos de precipitação. Revista Brasileira de Meteorologia, v. 33, n. 4, p. 601-613, 2018. http://dx.doi.org/10.1590/0102-7786334004

ARAI, F. K.; GONÇALVES, G. G. G.; PEREIRA, S. B.; PEIXOTO, P. P. P. Estudo do comportamento pluvial na região de Dourados, MS. Revista Agrarian, v. 2, n. 6, p. $105-$ $112,2009$.

ARAÚJO, W. F.; ANDRADE JÚNIOR, A. S.; MEDEIROS, R. D.; SAMPAIO, R. A. Precipitação pluviométrica mensal provável em Boa Vista, Estado de Roraima, Brasil. Revista Brasileira de Engenharia Agrícola e Ambiental, v. 5, n. 3, p. 563-567, 2001. http://dx.doi.org/10.1590/S1415-43662001000300032

BAPTISTA, M. B.; COELHO, M. M. L. P. Fundamentos de engenharia hidráulica. Belo Horizonte: UFMG, 2010. 473p.

BARBIERI, J. D.; DALLACORT, R.; FREITAS, P. S. L.; ARAÚJO, D. V.; TIEPPO, R. F.; FENNER, W. Effects of the ENSO on variability of precipitation and air temperature in agricultural regions do Mato Grosso State. Journal of agricultural Science, v. 11, n. 9, p. 91-102, 2019. https://dx.doi.org/10.5539/jas.v11n9p91

BAZAME, H. C.; ALTHOFT, D.; FILGUEIRAS, R.; ALVES, E. S. Rainfall spatio-temporal distribution of Western Bahia. Water Resources and Irrigation Management, v. 7, n. 2-3, p. 20-30, 2018.

BERMUDEZ, V. A. B.; ABILGOS, A. B. B.; CUARESMA, D. C. N.; RABAJANTE, J. F. Probability Distribution od Philippine Daily Rainfall Data. Preprints, 2017. https://dx.doi.org/10.20944/preprints201712.0150.v1

BEZERRA, R. B.; DANTAS, R. T.; TRINDADE, A. G. Caracterização temporal da precipitação pluvial do município de Porto Velho/RO no período de 1945 a 2003. Revista Sociedade \& Natureza, v. 22, n. 3, p. 609-623, 2010. https://doi.org/10.1590/S198245132010000300015

BORTOLUZZI, D. D.; PRADO, G.; HARA, A. T.; SOUZA, A. C. S. Precipitação mensal provável no noroeste do Paraná. Revista Brasileira de Agricultura Irrigada, v. 13, n. 2, p. 3314-3326, 2019. https://dx.doi.org/10.7127/rbai.v13n2001030

BRITO, R. S.; BRITO, RYCHAELLEN S.; MOREIRA, J. G. V.; OLIVEIRA, A. V. Produtividade de mandioca na região do Vale do Juruá, Amazônia Ocidental. Scientia Naturalis, v. 1, n.1, p. 1-9, 2019.

COSTA, K. T.; FERNANDES, W. S. Avaliação do tipo de distribuição de probabilidades das vazões máximas diárias anuais no Brasil. Revista Brasileira de Recursos Hídricos, v. 20, n. 2, p. 442-451, 2015. 
DALlACORT, R.; MARTINS, J. A.; INOUE, M. H.; FREITAS, P. S. L.; COLETTI, A. J. Distribuição das chuvas no município de Tangará da Serra, médio norte do Estado de Mato Grosso, Brasil. Acta Scientiarum. Agronomy, v. 33, n. 2, p. 193-200, 2011. https://dx.doi.org/10.4025/actasciagron.v33i2.5838

DELIGNETTE-MULlER, M. L.; DUTANG, C. Fitditrplus: An R Package for Fitting Distributions. Journal of Statistical Software, v. 8, p. 1-34, 2015.

FLORES, P. S. Cultivares de mandioca para a produção de farinha no estado do Acre. Rio Branco: Embrapa Acre, 2015.

IBGE. Clima do Brasil. 1:500.000. Available at: http://www.dados.gov.br/dataset/cren_climadobrasil_5000. Access: Dec. 2020.

LIMA, F. N.; NAGHETTINI, M.; ESPÓSITO, T. Avaliação da probabilidade de galgamento de barragem da PCH de Cajuru por simulação de Monte Carlo. Revista Brasileira de Recursos Hídricos, v. 20, n. 3, p. 722-730, 2015.

MARENGO, J. A.; SOUZA JÚNIOR, C. Mudanças Climáticas: impactos e cenários para a Amazônia. São Paulo: ALANA, 2018.

MARSAGLIA, G.; TSANG, W. W.; WANG, J. Evaluating Kolmogorov's Distribution. Journal of Statistical Software, v. 8, n.18, p. 1-4, 2003.

MARTINS, J. A.; DALlACORT, R.; INOUE, M. H.; SANTI, A.; KOLlING, E. M.; COLETTI, A. J. Probabilidade de precipitação pluviométrica para a microrregião de Tangará da Serra, Estado do Mato Grosso. Pesquisa Agropecuária Tropical, v. 40, n. 3, p. 291-296, 2010.

MIGUEZ, M. G.; DI GREGÓRIO, L. T.; VERÓL, A. P. Gestão de riscos e desastres hidrológicos. Rio de Janeiro: Elsevier, 2018.

MOREIRA, J. G. V.; CRAVEIRO, R. L.; SERRANO, R. O. P.; FORMOLO, A. K. Temporal trend and frequency of maximum precipitations in Cruzeiro do Sul, Acre, Brazil. Nativa, v. 4, n. 2, p. 97-102, 2016.

MOREIRA, J. G. V.; AQUINO, A. P. V.; MESQUITA, A. A.; MUNIZ, M. A.; SERRANO, R. O. P. Stationarity in annual daily maximum streamflow series in the upper Juruá River, western Amazon. Revista Brasileira de Geografia Física, v. 12, n. 12, p. 705-713, 2019. https://doi.org/10.26848/rbgf.v12.2.p705-713

MORETO, V. B.; APARECIDO, L. E. O.; ROLIM, G. S.; MORAES, J. R. S. C. Agrometeorological models for estimating sweet cassava yield. Pesquisa Agropecuária Tropical, v. 48, n. 1, p. 43-51, 2018. https://doi.org/10.1590/1983-40632018v4850451

NIMER, E. Um modelo metodológico da classificação de climas. Revista Brasileira de Geografia - IBGE, v. 41, n. 4, p. 59-89, 1979.

NOBRE, C. A.; SAMPAIO, G.; SALAZAR, L. Mudanças climáticas e Amazônia. Ciência e Cultura, v. 59, n. 3, p. 22-27, 2007.

NÓBREGA, R. S. Impactos do desmatamento e de mudanças climáticas nos recursos hídricos na Amazônia ocidental utilizando o modelo SLURP. Revista Brasileira de Meterologia, v. 29, p. 111-120, 2014. 
OLIVEIRA, L. F. C.; FIOREZE, A. P.; MEDEIROS, A. M. M.; SILVA, M. A. S. Comparação de metodologias de preenchimento de falhas de séries históricas de precipitação pluvial anual. Revista Brasileira de Engenharia Agrícola e Ambiental, v. 14, n. 11, p. 11861192, 2010. https://doi.org/10.1590/S1415-43662010001100008

PASSOS, M. L. V.; RAPOSO, A. B.; MENDES, T. J. Estimativa da distribuição da precipitação pluviométrica provável em diferentes níveis de probabilidade de ocorrência. Revista Brasileira de Agricultura Irrigada, v. 11, n. 1, p. 1106-1115, 2017. https://dx.doi.org/10.7127/rbai.v11n100498

PIZZATO, J. A.; DALlACORT, R.; TIEPPO, R. C.; MODOLO, A. J.; CREMON, C.; MOREIRA, P. S. P. Distribuição e probabilidade de ocorrência de precipitação em Cáceres (MT). Pesquisa Agropecuária Tropical, v. 42, n. 2, p. 137-142, 2012. http://dx.doi.org/10.1590/S1983-40632012000200006

SANTOS, D. C.; MEDEIROS, R. M.; CORREIA SANTOS, D.; BRITO, J. I. B. Variabilidade climática de regiões pluviometricamente homogêneas na Amazônia Ocidental. Revista Brasileira de Geografa Física, v. 6, n. 4, p. 903-918, 2013.

SANTOS, V. C.; BLANCO, C.; OLIVEIRA JÚNIOR, J. F. Distribution of rainfall probability in the Tapajos River Basin, Amazonia, Brazil. Revista Ambiente \& Água, v. 14, n. 3, 121, 2019. http://dx.doi.org/10.4136/ambi-agua.2284

SILVA, I. N. Precipitação provável para a região Centro-Sul do Ceará, Brasil. Revista Brasileira de Geografia Física, v. 8, n. 3, p. 751-758, 2015.

SILVA, R. S.; ZAVISLAK, F. D.; DALLACORT, R.; CARVALHO, M. A. C.; ARAÚJO, D. V. Distribuição de probabilidade de chuva no município de Sapezal, MT. Enciclopédia Biosfera, v. 9, n. 17, p. 1112-1122, 2013.

SILVA, E. G. F. A.; POLYCARPO, J. S. M.; MELO, R. F.; MOUSINHO, F. H. G.; OLIVEIRA FILHO, J. E.; CORREA, M. M. Determinação de precipitação provável mensal para o município de Goiana-PE. Revista GEAMA, v. 5, n. 1, p. 41-46, 2019.

SOMAN, S.; BYJU, G.; SREEKUMAR, J. Projected changes in mean temperature and total precipitation and climate suitability of cassava (Manihot esculenta) in maior growing environments of India. Indian Journal of Agricultural Sciences, v. 86, n. 5, p. 647-653, 2016.

SOUZA, L. D.; SOUZA, L. S.; GOMES, J. C. Exigências edáficas da cultura da mandioca. In: SOUZA, L. S.; FARIAS, A. R. N.; MATTOS, P. L. P.; FUKUDA, W. M. G. (Ed.). Aspectos socioeconômicos e agronômicos da mandioca. Cruz das Almas: Embrapa Mandioca e Fruticultura, 2006, p. 170-214.

SOUZA, L. P.; FARIAS, O. S.; MOREIRA, J. G. V.; GOMES, F. A.; FRADE JÚNIOR, E. F. Comparação de métodos de evapotranspiração de referência para o município de Cruzeiro do Sul-Acre. Enciclopédia Biosfera, v. 7, n. 12, p. 1-8, 2011.

SOUZA, D. O.; OLIVEIRA, F. G.; CASTRO, I. L.; SOARES, J. B. S.; REIS, M. M.; FIGUEIREDO, F. P. Frequência de ocorrência de precipitação pluviométrica em Montes Claros-MG. Revista Agrarian, v. 11, n. 42, p. 337-342, 2018. https://doi.org/10.30612/agrarian.v11i42.4175 
R CORE TEAM. R: A language and environment for statistical computing. Vienna: $\mathrm{R}$ Foundation for Statistical Computing, 2019.

TEIXEIRA, C. F. A.; DAMÉ, R. C. F.; BACELAR, L. C. S.; SILVA, G. M.; COUTO, R. S. Intensidade da seca utilizando índices de precipitação. Revista Ambiente \& Água, v. 8, n. 3, p. 203-213, 2013. https://doi.org/10.4136/ambi-agua.1245 